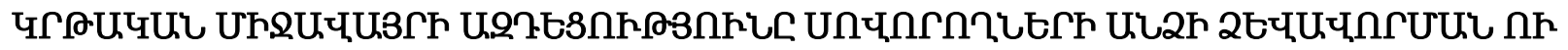 शUrqu.sUUน चุU.
}

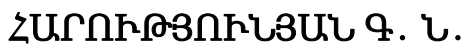

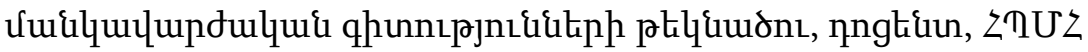

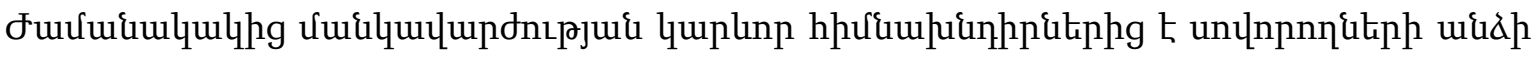

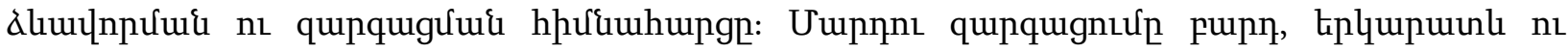

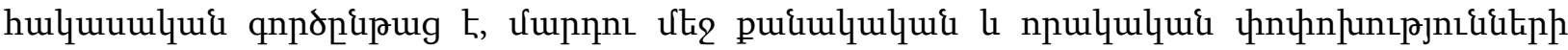

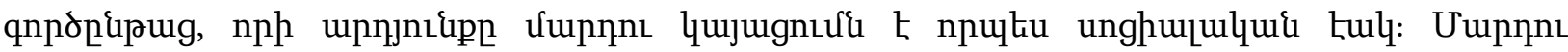

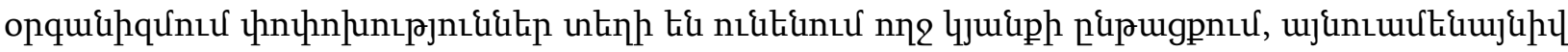

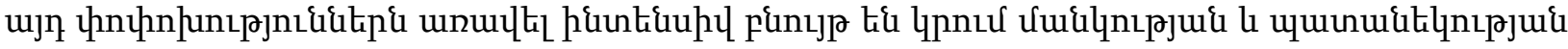

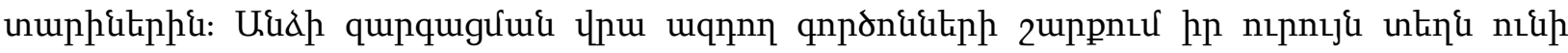

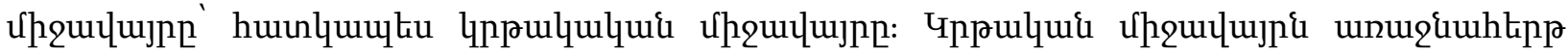

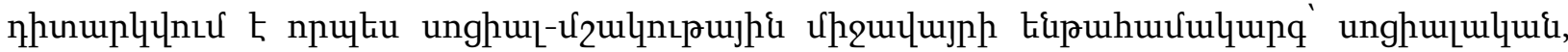

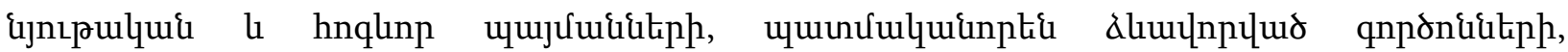

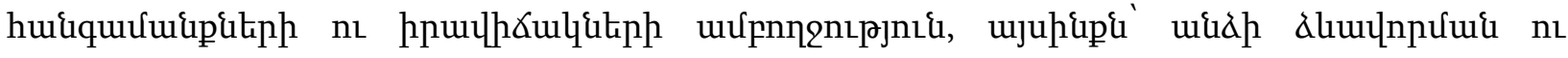

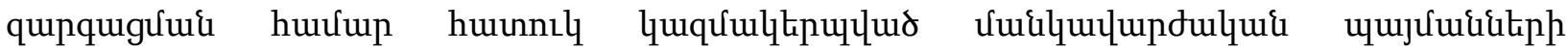

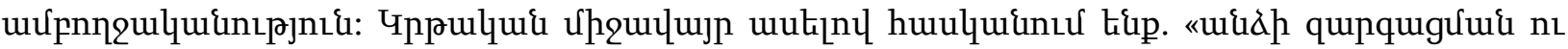

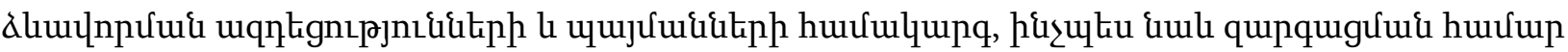

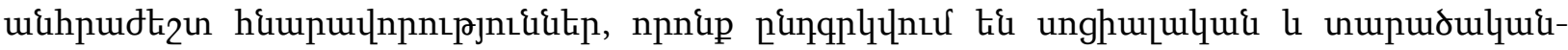
opjtilunhl úpquulujnnıu» [1, te 145]:

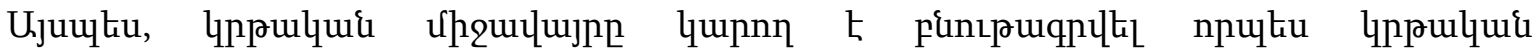

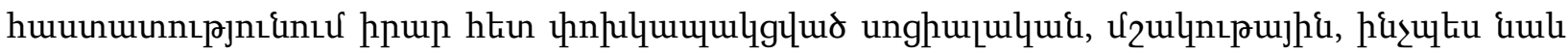

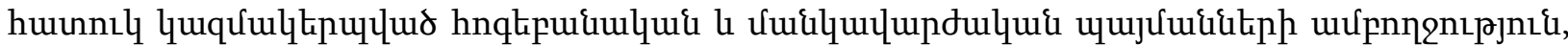

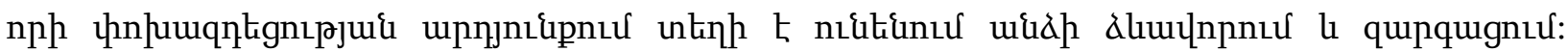

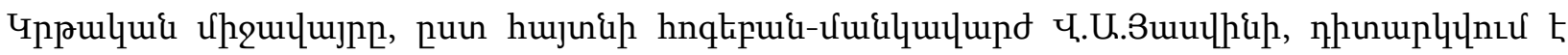

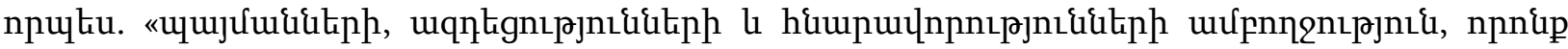

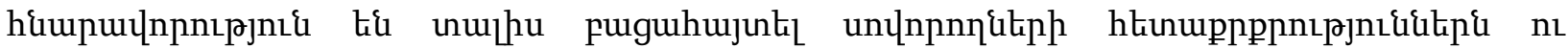

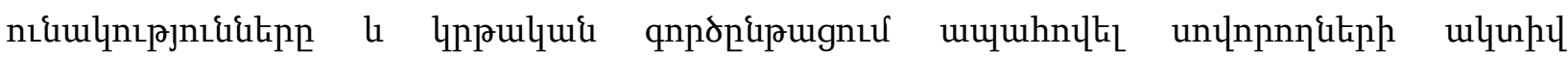

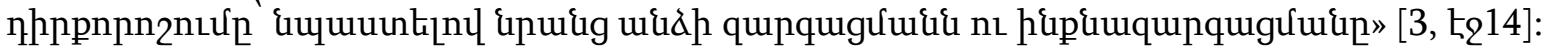

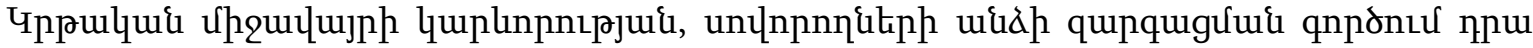

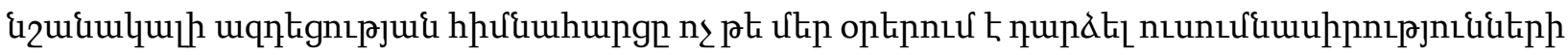

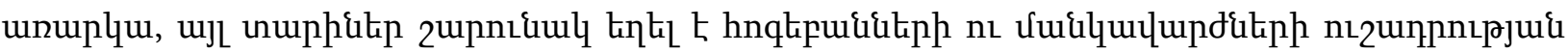




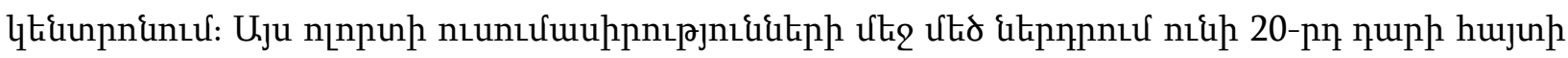

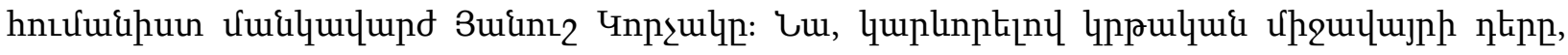

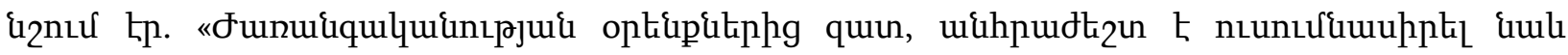

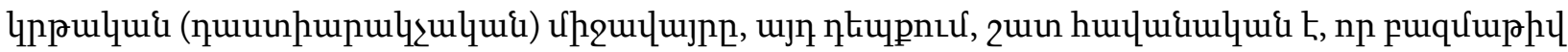

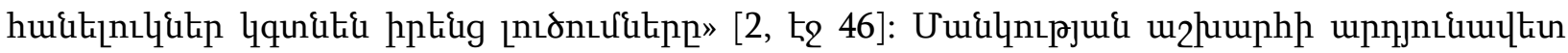

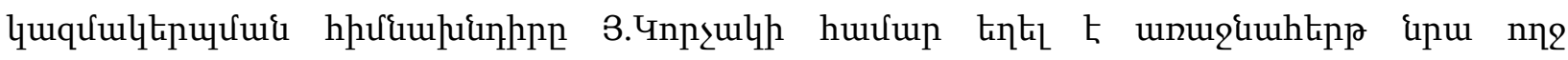

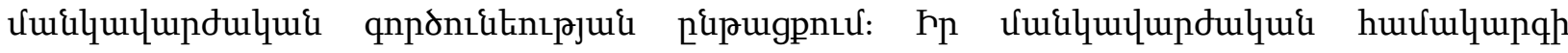

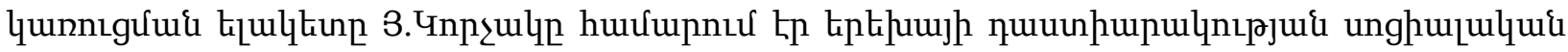

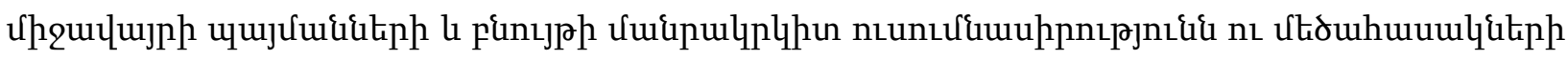

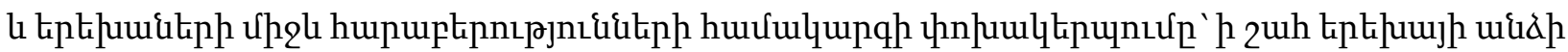

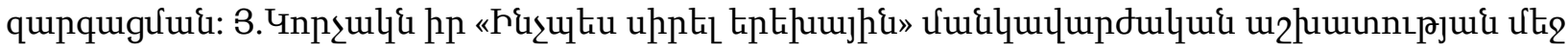

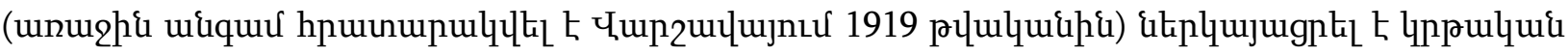

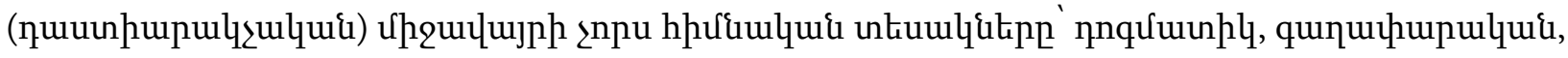

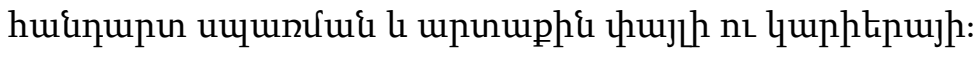

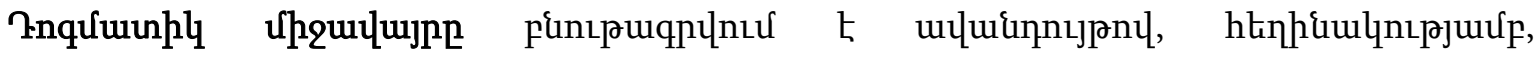

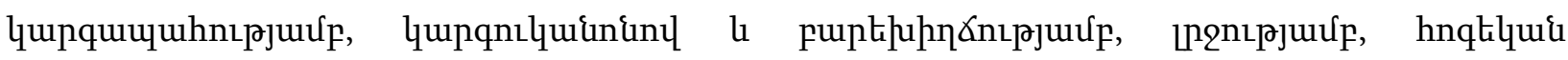

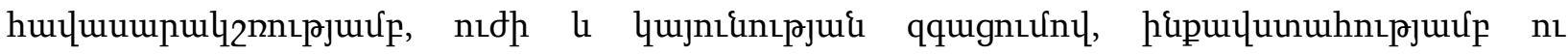

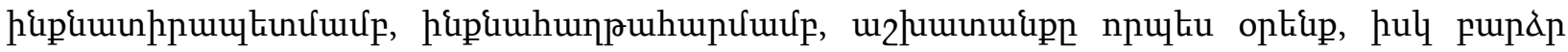

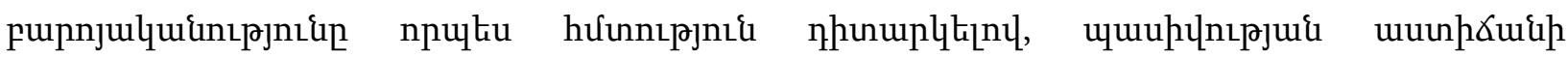

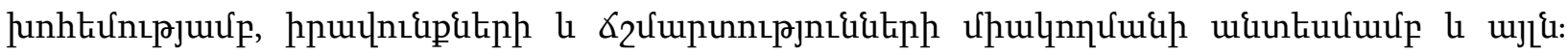

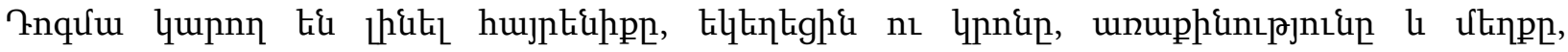

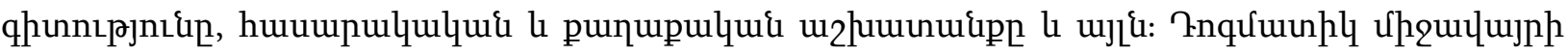

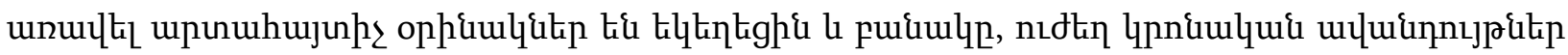

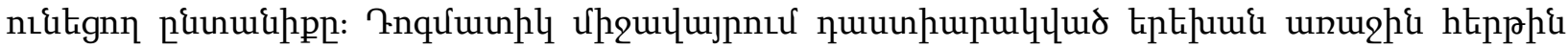

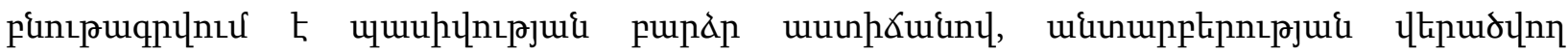

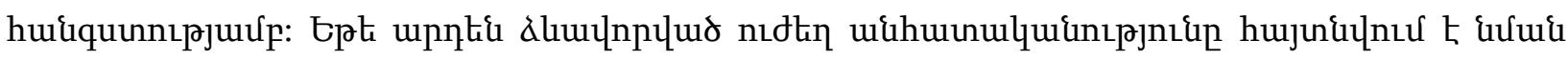

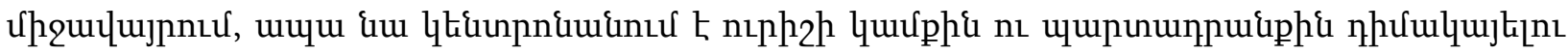

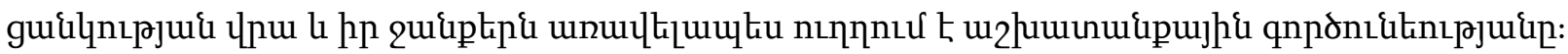

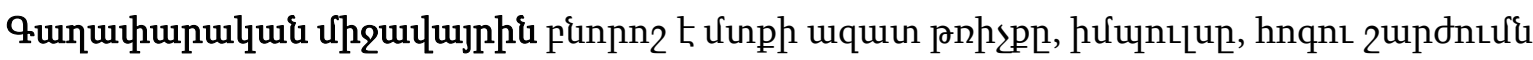

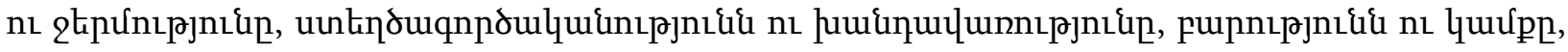

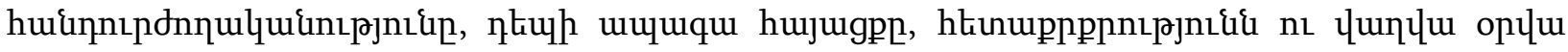

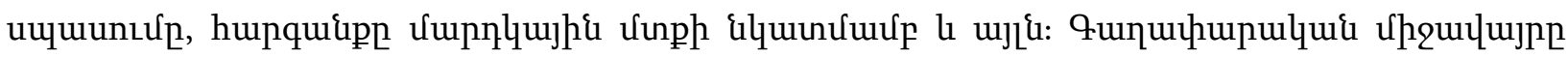

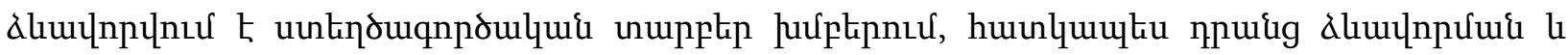




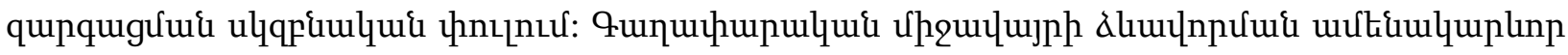

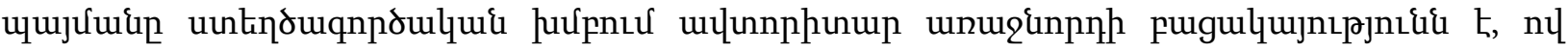

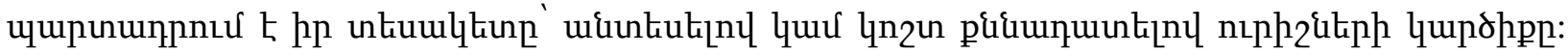

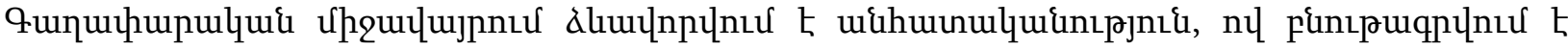

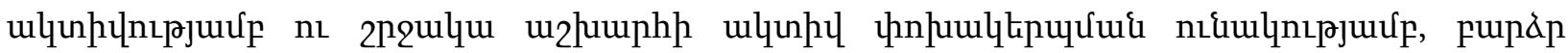

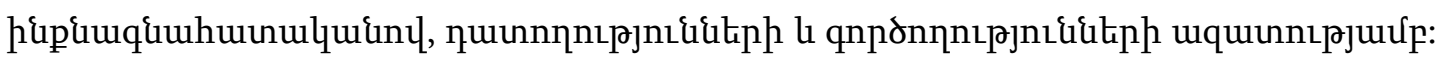

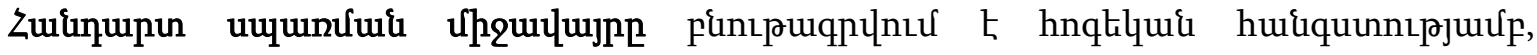

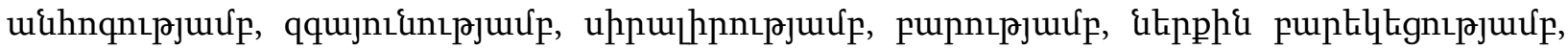

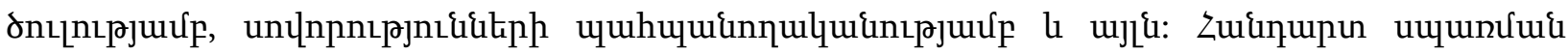

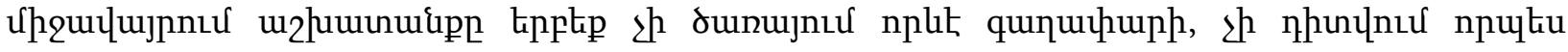

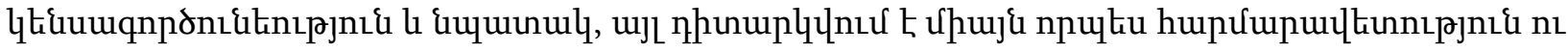

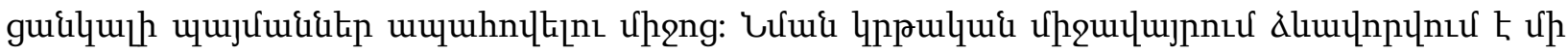

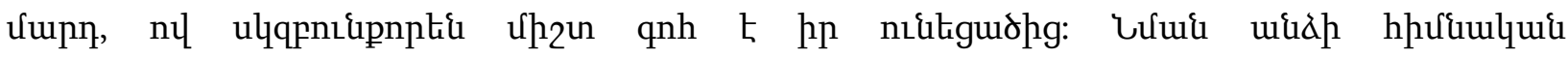

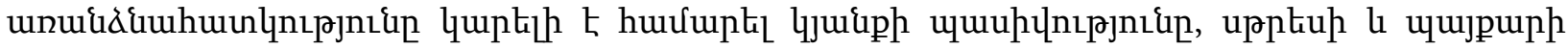

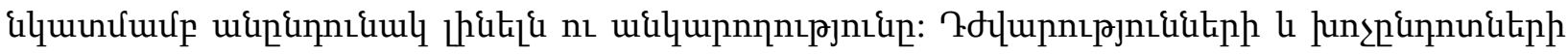

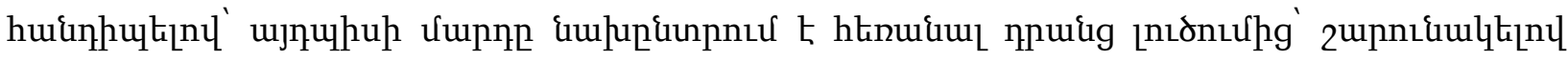

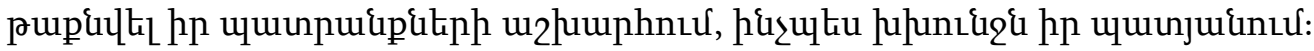

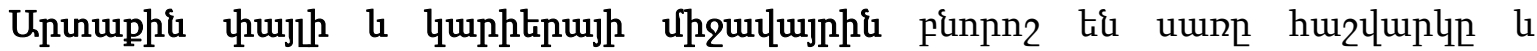

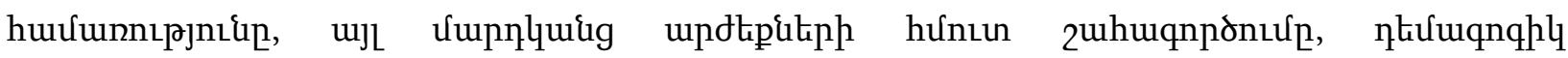

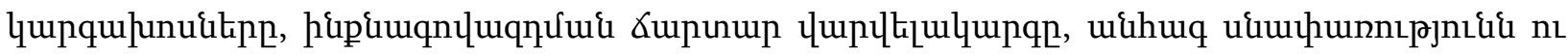

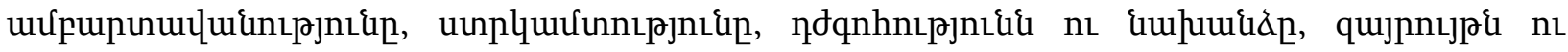

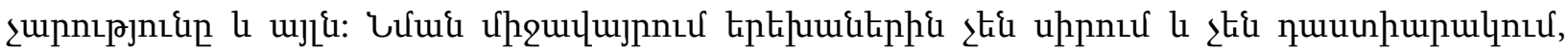

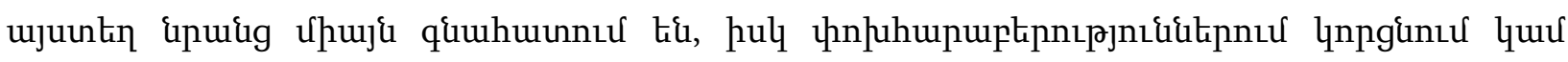

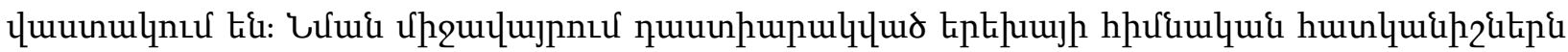

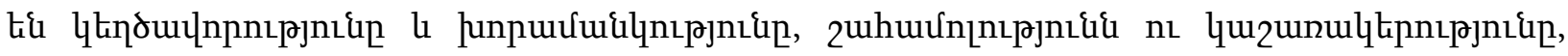

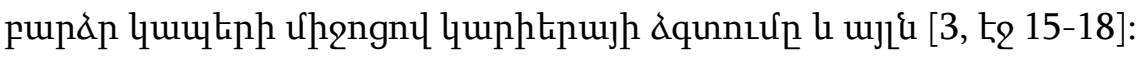

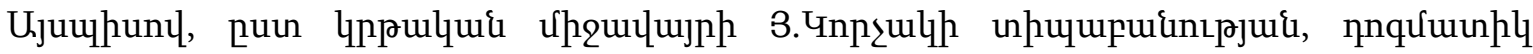

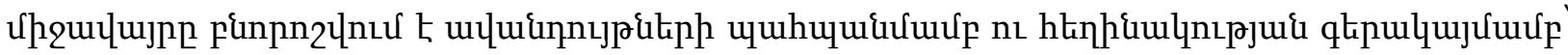

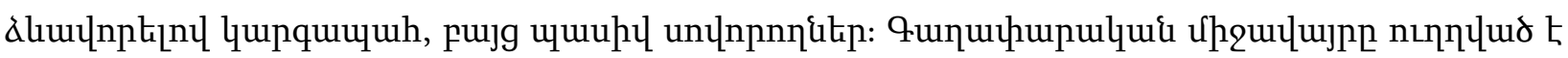

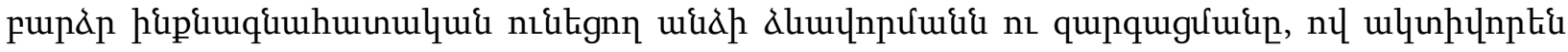

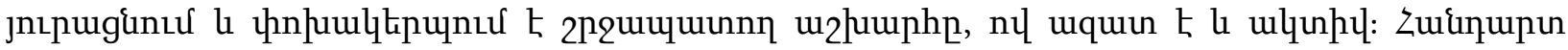

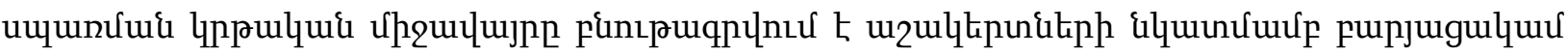

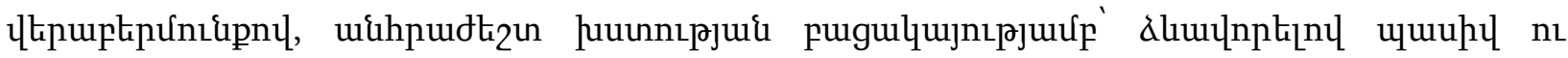




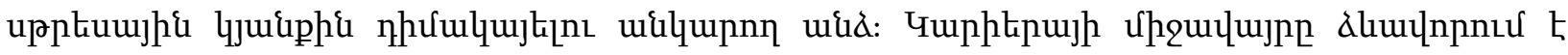

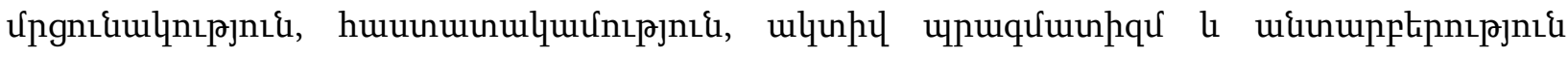

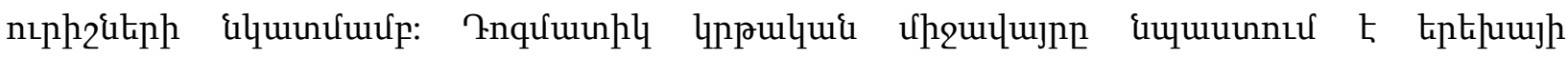

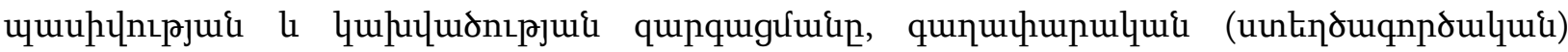

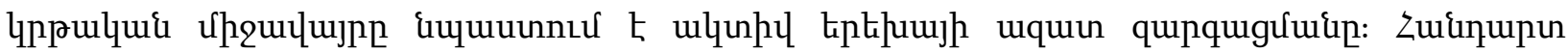

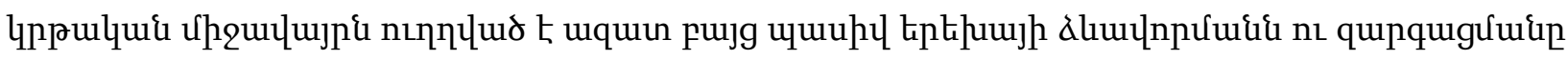

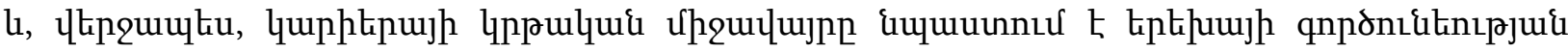

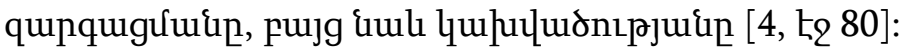

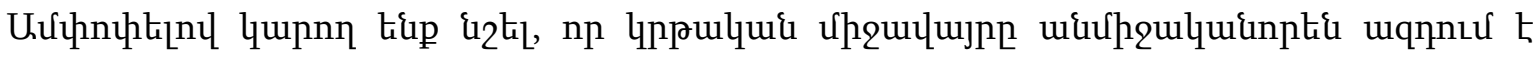

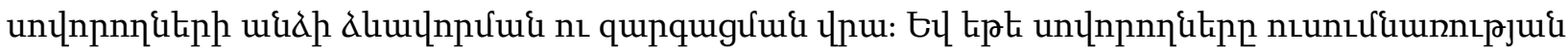

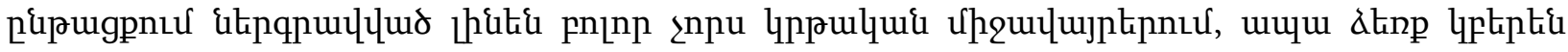

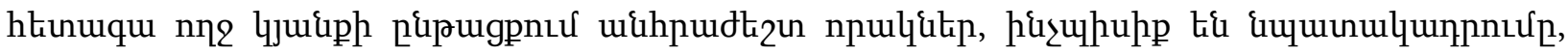

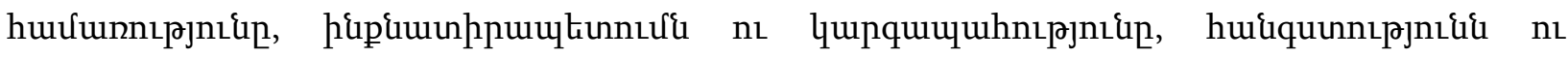

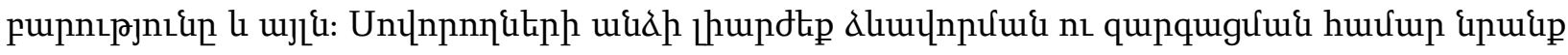

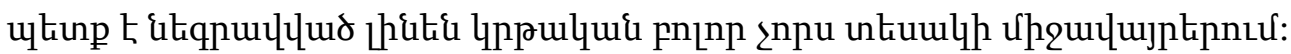

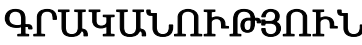

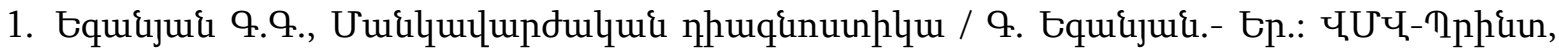
2020, 232 t?:

2. Януш Корчак Как любить ребенка.- М: Изд. АСТ.- 2014.- 390 с.

3. Ясвин В.А. Образовательная среда: от моделирования к проектированию.- М.: Смысл.2001.- 365 c.

4. Ясвин В.А. Школьная среда как предмет измерения: экспертиза, проектирование, управление / В.А. Ясвин. - М.: Народное образование .- 2019.- 448 с.

\section{THE INFLUENCE OF THE EDUCATIONAL ENVIRONMENT ON THE FORMATION AND DEVELOPMENT OF THE PERSONALITY OF STUDENTS}

The environment, especially the educational environment, occupies a special place among the factors influencing the formation and development of the personality of students. In his main pedagogical work, Korczak distinguishes four types of educational environment: dogmatic, ideological, environment of serene consumption and environment of outward gloss and career. For full-fledged formation, the student must pass all four types of educational environments. 
Keywords: educational environment, influence, personality development, discipline, career, heredity. 